\title{
Investment Horizon and the Choice of Mutual Fund
}

\author{
Felicia Y. Amadi ${ }^{1} \&$ Confidence W. Amadi ${ }^{1}$ \\ ${ }^{1}$ Department of Business \& Economics, Elizabeth City State University, Elizabeth City, North Carolina, USA \\ Correspondence: Confidence W. Amadi, 1704 Weeksville Road, Elizabeth City State University, Elizabeth City, \\ NC 27909. USA. E-mail: cwamadi@ecsu.edu
}

Received: April 12019

Accepted: April 30, 2019

Online Published: May 16, 2019

doi:10.5539/ijbm.v14n6p76

URL: https://doi.org/10.5539/ijbm.v14n6p76

\begin{abstract}
The purpose of this study is to explore the relationship between the choice of mutual fund investment style and investor investment horizon. The investment style is characterized as a measure of the riskiness of the mutual fund and therefore the required/expected return of a mutual fund ranging from large cap value to small cap growth. The results of this study show that investment horizon and investment style are inter-related. Longer investment horizons are best suited for small cap value and small cap growth. In general, for each investment horizon, the large cap value style had the lowest expected return as evidenced by its beta coefficient. The investment style with the highest expected return depends on the investment horizon.
\end{abstract}

Keywords: investment style, mutual fund performance, mutual fund risk

\section{Introduction}

Total net assets of worldwide regulated open-end funds increased from \$21.7 trillion in 2008 to $\$ 49.3$ trillion in 2017 according to the Investment Company Institute facebook (2018), net sales increased from \$-342 billion in 2008 to $\$ 2117$ billion in 2017. The assets of US-registered investment company exceeded $\$ 22$ trillion in 2017 compared to $\$ 10.364$ trillion in 2008. The number of Investment Companies went from16,247 in 2008 to 16818 in 2017. Households (retail) investors held $90 \%$ of the $\$ 18.7$ trillion in U.S. mutual fund total assets. These statistics underscore the importance of mutual funds within the economy. There are nine major investment styles, ranging from large capitalization value to small capitalization growth, within the mutual fund universe. This classification in theory is supposed to reflect increasing risk as one goes from large capitalization value to small capitalization growth. How investors choose among these styles is style not clearly understood. Research in this area generally point to past performance as the metric used by investors to select mutual funds to add to their portfolio. Cashman et al (2012) conducted a study on investor behavior. They find that equity fund investors are more active monitors of fund performance than hybrid fund investors. In addition, they find that net flows "respond both contemporaneously and with a lag to fund performance."

The purpose of this study is to explore the relationship between the choice of mutual fund investment style and investor investment horizon. The investment style is characterized as a measure of the riskiness of the mutual fund and therefore the required/expected return of a mutual fund ranging from large cap value to small cap growth. Several studies have addressed the performance of mutual fund on various dimensions and factors (e.g. Peterson, Pietranico, Riepe, \& Xu, 2002; Chander, 2002; Nihar \& Murty, 2010). The consensus is that risk, investment style, past pretax performance, turnover, and fund expenses are important determinants of pretax equity mutual fund returns. Investors use these variables to assess the investment prospects of mutual fund. This paper on the other hand explores the performance of mutual fund styles against investment horizon. We hypothesize that the longer the investment horizon, the less relevant investment style is to the performance of the mutual fund. The rest of the paper is organized as follows: section II is a brief literature review, section III addresses data and methodology, section IV presents results and analysis, while section V presents the conclusion.

\section{Brief Literature Review}

In his paper on mutual fund selection, Nanigian (2015) suggests that financial planners "look for funds with a high level of fund manager ownership, board of director ownership, a short term redemption fee, a high active share or low R-squared value, and a lack of affiliation with an investment bank." In addition, he reports on literature review that suggests that fund managers should also look for funds that manage their portfolio in-house, 
outsource the execution of their shareholder services, have managers with their compensation linked to performance, and have a key role in their fund family performed by someone with a Ph.D. He observes that each of this characteristics are associated with outperformance.

Lin (2006) examined the determinants of mutual fund performance over different investment horizons. Lin finds that the fund performance is relevant with the length of the investment horizon. The study data is Taiwan mutual funds, with funds being classified as aggressive-growth, growth and income and growth fund. The study finds that growth and income funds have the best performance when the investment horizon is less than three years. However, for horizon between three and four years, growth funds are better while aggressive-growth funds are the best when investment horizon is less than one year and greater than four years. The present study looks at nine categories of investment style and covers periods of up to ten years. Secondly, our study is based on US mutual funds as listed on Fidelity website.

Lobao and Gomes (2015) studied the performance and characteristics of mutual funds. They focus on seven classes of funds: US Equity funds, EU, Switzerland and Norway Equity funds, International Equity fund, Portuguese Equity funds, Euro Variable-income funds, Euro Fixed-income funds and lastly, Euro Money Market funds. Using Jensen's alpha as a measure of performance, they show that the sum of the fees charged by the fund, the overall costs supported by the fund, the size of the fund, the net flow of funds to the fund, the historical performance of the fund, the age of the fund, the risk class of the fund, and the average portfolio turnover were significant in explaining the variation in fund performance. Specifically, although the impact of these variables were significant, the direction of their effect varied by fund class. For example, the results indicate a negative relationship with EU, Switzerland and Norway equity funds, but a positive effect on Portuguese equity fund. Similarly, size has a negative impact on international equity fund and US equity fund. As for net flows, it has a positive effect on international equity fund and US equity funds. In addition, historical performance although significant, its direction was different for each fund class. The same thing is true for the other variables like age, and turnover. The takeaway from this study is that while they affect the performance as measured by Jensen's alpha, other factors are at play in determining the direction of the effects of this variable. It also implies that the investor could enhance their return by choice of funds with the appropriate characteristics.

Arugaslan et al (2007) evaluated large US-based equity mutual funds using risk-adjusted performance measures in an effort to provide empirical evidence that can be used as input in decision making by investors who are interested in participating in the stock market via mutual funds. The funds were ranked based on unadjusted returns as well as risk adjusted returns by Sortino Ratios, $\beta, M^{2}$ measures, Jensen's alpha, Treynor measures and Sharp ratio. The rankings were significantly different with some high ranked funds reverting to lower ranking. As fund flows tend to follow performance, adjusting the funds returns can help investors make better comparison between funds.

Switzer and Huang (2007) examined the impact of fund manager human capital characteristics such as tenure, investment experience, education (MBA designation), professional training (CFA), and gender on the performance of small and mid-cap mutual funds. They find that longer tenure and longer investment experience are not related to better fund performance, but rather to higher expense rations. They also find that CFAs and women are more active traders with higher turnover; and that women in addition tend to incur higher systematic risk $(\beta)$ in their portfolios. In addition, they find that risk-adjusted performance is inversely related to asset size.

Haslem (2014) reviewed Morningstar analytical grading measures used by investors to select mutual funds. The grading measures include "Morningstar star ratings, analyst ratings, total pillar ratings, upside and downside capture ratios, and the stewardship ratings." Haslem proposes and tests a model to evaluate the effectiveness of these Morningstar rating systems. The study finds that Morningstar ratings do predict low-performing funds. Funds with fewer than three stars generally have worse performance than other rated funds. Also, there is weak evidence that five-star funds outperform four- and three-star funds. In addition, the study finds that Morningstar ratings do only slightly better than alternative predictors such as the Sharpe ratios, Jensen and four index alphas, in forecasting fund performance. Even though Morningstar clearly states that star ratings are not predictors of future fund performance, higher star ratings are strongly related to large fund inflows and are widely used in advertising.

Jones et al (2005) provides the survey results from over 500 financial advisors regarding their decision process in buying mutual funds. The results indicate that financial advisors place the most importance in comprehensive data sources such as Morningstar and Lipper. The second and third most important information sources are independent rankings such as Lipper and Morningstar and the research provided by the advisor's company. On fund characteristics, the study shows that performance relative to funds in similar style, fund objective, fund risk, 
fund manager tenure, and fund manager reputation are the top five fund characteristics that advisors look out for. On the other hand, as reported by Jones et al (2005), individual investors rely heavily on mutual fund advertising and on raw returns when making fund purchase decisions.

Target date funds are funds that approximates matching the portfolio to the investor's investment horizon. They target specific retirement years. Booth and Chang (2011) studied the performance of these funds. They find that "the 2010 date funds significantly increased their common equity exposure in 2007, immediately prior to the stock market crash of 2008, resulting in significant losses for investors planning to retire in 2010". They also find that these funds hold $75 \%$ in equity resulting in a $30 \%$ plus loss in 2008 ; this is bad news.

Holmes and Faff (2007) studied the linkages between style drift, fund flow and fund performance. They find no relationship between fund flow and fund size, style drift, or performance. They find that successful stock pickers "tend to be more variable in style, but that this variability is unrelated to fund flow volatility". Jamaludin et al (2012) surveyed 440 Malaysian Employee Provident Fund to explore perceived importance of fund selection criteria within the context of retirement savings. They find that among the non-Muslims, the most important criteria were past performance. However, both Muslims and non-Muslims valued the overall reputation of the fund as important criterion in selecting a mutual fund.

\section{Data and Methodology}

The data for this study was retrieved from Fidelity.com on May 20, 2018 at 11:0am. It consists of all the equity mutual fund listed on the website. The variables of interest are the investment style, expense ratio and the one-, three-, five-, and ten-year annualized returns. A cross-sectional analysis of the relationship between portfolio return and portfolio style is performed to determine if there is a variation in return based on portfolio style. Expense ratio is used to control for trading activities of the portfolio manager. The OLS regression is of the form:

$$
\mathrm{R}_{\mathrm{pi}}=\alpha_{\mathrm{i}}+\beta_{1 \mathrm{i}} \mathrm{LV}+\beta_{2 \mathrm{i}} \mathrm{LB}+\beta_{3 \mathrm{i}} \mathrm{LG}+\beta_{4 \mathrm{i}} \mathrm{MV}+\beta_{5 \mathrm{i}} \mathrm{MB}+\beta_{6 \mathrm{i}} \mathrm{MG}+\beta_{7 \mathrm{i}} \mathrm{SV}+\beta_{8 \mathrm{i}} \mathrm{SB}+\beta_{9 \mathrm{i}} \mathrm{SG}+\beta_{10 \mathrm{i}} \mathrm{EXP}+\varepsilon_{\mathrm{i}}
$$

Where $\mathrm{R}_{\mathrm{pi}}$ is the portfolio annualized return for holding period $i$

$\beta_{\mathrm{ij}}$ are the regression coefficients;

$\mathrm{LV}$ is large cap value style;

LB is large cap blend style;

LG is large cap growth style;

MV is mid cap value style;

MB is mid cap blend style;

MG is mid cap growth style;

$\mathrm{SV}$ is small cap value style;

SB is small cap blend style;

EXP is expense ratio;

$\varepsilon$ is the error term;

The null hypothesis $\left(\mathrm{H}_{0}\right)$ is that the coefficients are not significantly different from zero for each holding period. The alternate $\left(\mathrm{H}_{\mathrm{a}}\right)$ is that some of the coefficients are significantly different from zero for some of the holding periods.

\section{Results}

The results of the OLS regression are presented in tables 1 through 5. The results indicate that for each of the investment horizon, the style variables are statistically significant. However, their effect is negative for all the investment horizon, with betas varying by investment style and investment horizon. Table 1 shows the regression results for the YTD investment horizon. The results show an adjusted R-squared of $45.1 \%$ with an F-value of 98.761. The large value investment style had the highest effect with a standardized beta coefficient of -0.604 while medium cap growth style variable had the least statistically significant effect with a coefficient of -0.057 . Thus, with the year-to-date, that is under one year, median cap investment style may be most appropriate. 
Table 1. Regression results for YTD investment horizon

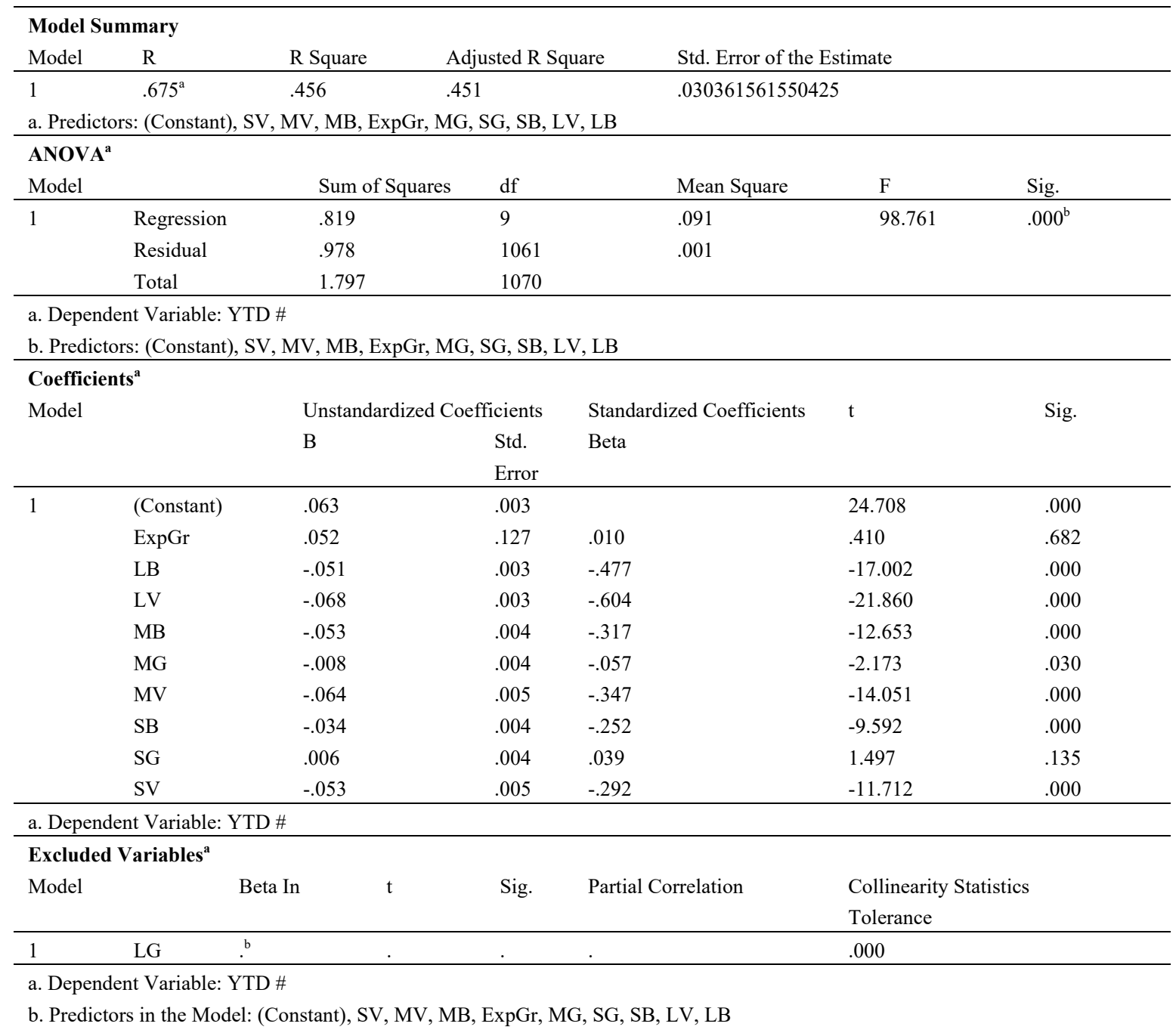

Table 2 presents the regression results for the one-year investment horizon. The adjusted R-squared is $41 \%$ with an F-statistic of 83.158. The significant standardized beta coefficient ranged from -0.521 for the large cap value investment style to -0.102 for the medium cap growth style. Thus, with a one-year investment horizon, the mid-cap investment style is the most appropriate.

Table 2. Regression results for 1year investment horizon

\begin{tabular}{|c|c|c|c|c|c|c|}
\hline \multicolumn{7}{|c|}{ Model Summary } \\
\hline Model & $\mathrm{R}$ & R Square & \multicolumn{2}{|c|}{ Adjusted R Square } & \multicolumn{2}{|c|}{ Std. Error of the Estimate } \\
\hline 1 & $.645^{\mathrm{a}}$ & .415 & \multicolumn{2}{|l|}{.410} & \multicolumn{2}{|c|}{.049031528932158} \\
\hline \multicolumn{7}{|c|}{ a. Predictors: (Constant), SV, MV, MB, ExpGr, MG, SG, SB, LV, LB } \\
\hline \multicolumn{7}{|c|}{ ANOVA $^{a}$} \\
\hline Model & & Sum of Squares & df & Mean Square & $\mathrm{F}$ & Sig. \\
\hline \multirow[t]{3}{*}{1} & Regression & 1.799 & 9 & .200 & 83.158 & $.000^{\mathrm{b}}$ \\
\hline & Residual & 2.532 & 1053 & .002 & & \\
\hline & Total & 4.331 & 1062 & & & \\
\hline
\end{tabular}

a. Dependent Variable: 1 Yr

b. Predictors: (Constant), SV, MV, MB, ExpGr, MG, SG, SB, LV, LB 


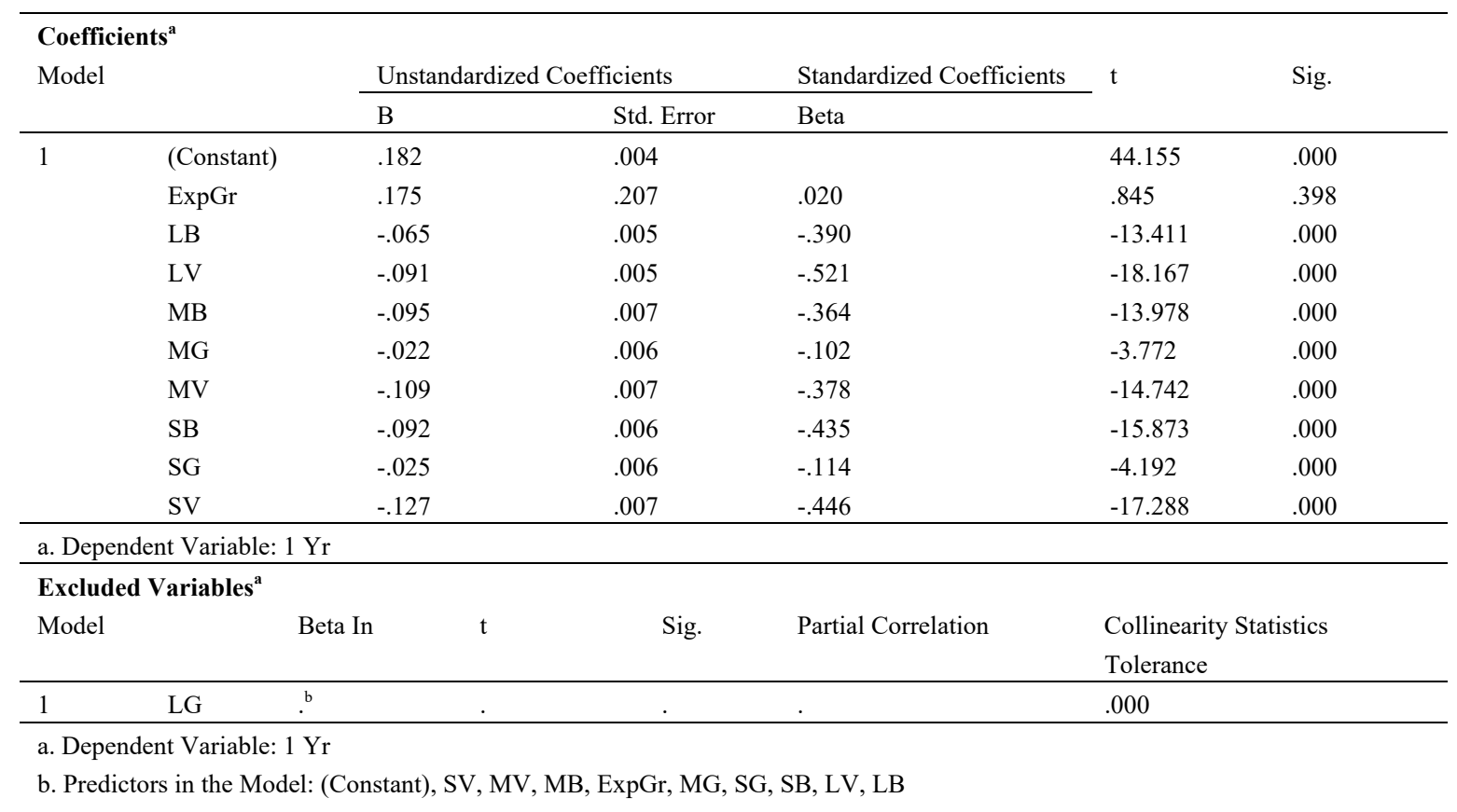

In Table 3, the regression results for the 3-year investment horizon, indicates that the large value investment style had the most effect on returns with a standardized beta coefficient of -0.411 . Small Cap growth had the lowest standardized beta coefficient of -0.106 . The regression had an adjusted R-squared of $23.6 \%$ with an F-statistic of 36.071. Thus, the small cap growth investment style appears to be the preferred investment style for a 3-year investment horizon.

Table 3. Regression result for 3year investment horizon

\begin{tabular}{|c|c|c|c|c|c|c|c|}
\hline \multicolumn{8}{|c|}{ Model Summary } \\
\hline Model & $\mathrm{R}$ & R Square & \multicolumn{2}{|c|}{ Adjusted R Square } & \multicolumn{3}{|c|}{ Std. Error of the Estimate } \\
\hline 1 & $.493^{\mathrm{a}}$ & .243 & \multicolumn{2}{|l|}{.236} & \multicolumn{3}{|l|}{.026561701580237} \\
\hline \multicolumn{8}{|c|}{ a. Predictors: (Constant), SV, MV, ExpGr, MB, SB, MG, SG, LV, LB } \\
\hline \multicolumn{8}{|c|}{ ANOVA $^{\mathrm{a}}$} \\
\hline \multicolumn{2}{|c|}{ Model } & Sum of Squares & $\mathrm{df}$ & \multicolumn{2}{|r|}{ Mean Square } & $\mathrm{F}$ & Sig. \\
\hline \multirow[t]{3}{*}{1} & Regression & .229 & 9 & & .025 & \multirow[t]{3}{*}{36.071} & \multirow[t]{3}{*}{$.000^{\mathrm{b}}$} \\
\hline & Residual & .715 & 1013 & & .001 & & \\
\hline & Total & .944 & 1022 & & & & \\
\hline \multicolumn{8}{|c|}{ a. Dependent Variable: 3 Yr } \\
\hline \multicolumn{8}{|c|}{ b. Predictors: (Constant), SV, MV, ExpGr, MB, SB, MG, SG, LV, LB } \\
\hline \multicolumn{8}{|c|}{ Coefficients $^{\mathrm{a}}$} \\
\hline \multirow[t]{2}{*}{ Model } & & \multicolumn{2}{|c|}{ Unstandardized Coefficients } & \multirow{2}{*}{\multicolumn{2}{|c|}{$\begin{array}{l}\text { Standardized Coefficients } \\
\text { Beta }\end{array}$}} & \multirow[t]{2}{*}{$\mathrm{t}$} & \multirow[t]{2}{*}{ Sig. } \\
\hline & & $\mathrm{B}$ & Std. Error & & & & \\
\hline \multirow[t]{10}{*}{1} & (Constant) & .112 & .002 & & & 47.462 & .000 \\
\hline & ExpGr & -.378 & .125 & -.085 & & -3.013 & .003 \\
\hline & LB & -.020 & .003 & -.251 & & -7.392 & .000 \\
\hline & LV & -.034 & .003 & -.411 & & -12.365 & .000 \\
\hline & MB & -.044 & .004 & -.349 & & -11.569 & .000 \\
\hline & MG & -.022 & .003 & -.218 & & -6.872 & .000 \\
\hline & MV & -.044 & .004 & -.324 & & -10.846 & .000 \\
\hline & SB & -.025 & .003 & -.243 & & -7.692 & .000 \\
\hline & SG & -.011 & .003 & -.106 & & -3.344 & .001 \\
\hline & SV & -.043 & .004 & -.310 & & -10.400 & .000 \\
\hline
\end{tabular}

a. Dependent Variable: $3 \mathrm{Yr}$ 


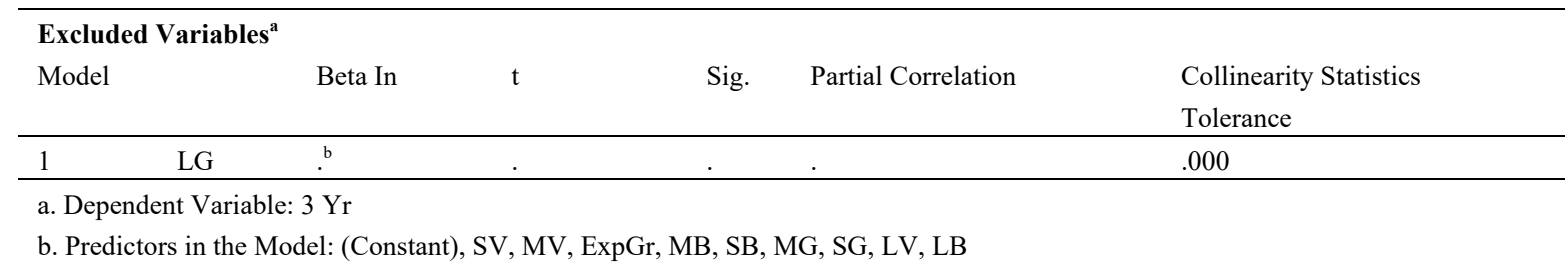

Table 4 presents the results for the five-year investment horizon. The regression adjusted R-squared is $35.7 \%$, with an F-statistic of 60.917 . The value of the standardized beta coefficient ranged from - 0.508 for large cap value investment style to -0.137 for the small cap growth style. Similarly, Table 5 presents the results for the ten-year investment horizon. The adjusted R-squared is $22.1 \%$ with an F-statistics of 27.199 . The standardized beta coefficient ranged from -0.433 to -0.073 for large cap value and small cap value styles, respectively.

Table 4. Regression results for 5year investment horizon

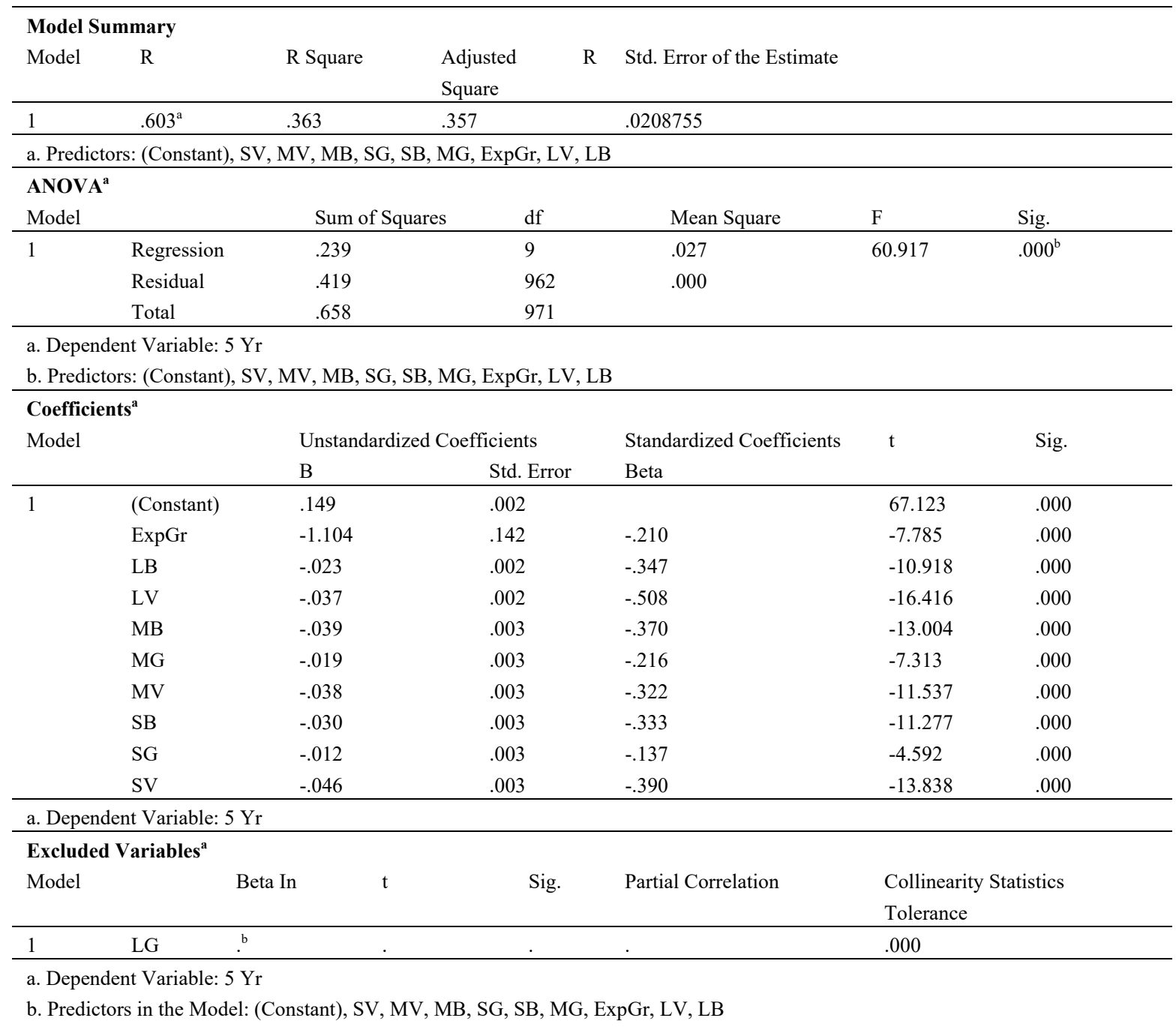

In general, for each investment horizon, the large cap value style had the lowest expected return as evidenced by its beta coefficient. The investment style with the highest expected return depends on the investment horizon. For the YTD and the one-year horizon, the mid cap growth investment style had the highest expected return. On the other hand, the small cap growth investment style had the highest expected return for the three- and five-year horizon. However, for the ten-year horizon, small cap value style had the highest expected return. 
Table 5. Regression Results for 10year Investment Horizon

\begin{tabular}{|c|c|c|c|c|c|c|c|}
\hline \multicolumn{8}{|c|}{ Model Summary } \\
\hline Model & \multirow{2}{*}{$\frac{\mathrm{R}}{479^{\mathrm{a}}}$} & \multicolumn{2}{|c|}{ R Square } & Adjusted R Square & \multicolumn{2}{|c|}{ Std. Error of the Estimate } & \\
\hline 1 & & & 230 & .221 & .0156896 & & \\
\hline \multicolumn{8}{|c|}{ a. Predictors: (Constant), SV, MV, MB, ExpGr, MG, SB, LV, SG, LB } \\
\hline \multicolumn{8}{|c|}{ ANOVA $^{\mathrm{a}}$} \\
\hline \multicolumn{2}{|l|}{ Model } & & Sum of Square & $\mathrm{df}$ & Mean Square & $\mathrm{F}$ & Sig. \\
\hline \multirow[t]{3}{*}{1} & Regression & & .060 & 9 & .007 & 27.199 & $.000^{\mathrm{b}}$ \\
\hline & Residual & & .202 & 821 & .000 & & \\
\hline & Total & & .262 & 830 & & & \\
\hline \multicolumn{8}{|c|}{ a. Dependent Variable: $10 \mathrm{Yr}$} \\
\hline \multicolumn{8}{|c|}{ b. Predictors: (Constant), SV, MV, MB, ExpGr, MG, SB, LV, SG, LB } \\
\hline \multicolumn{8}{|c|}{ Coefficients $^{\mathrm{a}}$} \\
\hline \multirow[t]{2}{*}{ Model } & & \multicolumn{3}{|c|}{ Unstandardized Coefficients } & Standardized Coefficients & $\mathrm{t}$ & Sig. \\
\hline & & & $\mathrm{B}$ & Std. Error & Beta & & \\
\hline \multirow[t]{10}{*}{1} & (Constant) & & .106 & .002 & & 50.856 & .000 \\
\hline & ExpGr & & -1.192 & .150 & -.263 & -7.969 & .000 \\
\hline & LB & & -.012 & .002 & -.260 & -6.821 & .000 \\
\hline & LV & & -.022 & .002 & -.433 & -11.755 & .000 \\
\hline & MB & & -.011 & .002 & -.152 & -4.527 & .000 \\
\hline & MG & & -.006 & .002 & -.106 & -2.995 & .003 \\
\hline & MV & & -.011 & .003 & -.142 & -4.259 & .000 \\
\hline & SB & & -.006 & .002 & -.095 & -2.707 & .007 \\
\hline & SG & & .007 & .002 & .117 & 3.224 & .001 \\
\hline & SV & & -.006 & .003 & -.073 & -2.205 & .028 \\
\hline \multicolumn{8}{|c|}{ a. $\quad$ Dependent Variable: $10 \mathrm{Yr}$} \\
\hline \multicolumn{8}{|c|}{ Excluded Variables $^{\mathrm{a}}$} \\
\hline \multirow[t]{2}{*}{ Model } & & Beta In & $\mathrm{t}$ & Sig. & Partial Correlation & \multicolumn{2}{|c|}{ Collinearity Statistics } \\
\hline & & & & & & Tolerance & \\
\hline 1 & LG & $.000^{\mathrm{b}}$ & .000 & 1.000 & .000 & $4.996 \mathrm{E}-14$ & \\
\hline
\end{tabular}

\section{Conclusion}

The objective of this paper is to investigate the relationship between investment style and returns and investment horizon. The study finds that the Large Cap Value investment style has the lowest expected return for all the horizon studied. This is consistent with the risk/return tradeoff. The large cap value fund is the least risky of all the nine investment styles. However, for the style that has the highest expected return, the results are mixed. For short term, one year or less, the mid cap investment style has the highest expected return. For three and five years, small cap growth investment style dominated. For ten years, the small cap value seems to dominate.

The results of this study show that investment horizon and investment style are inter-related. Longer investment horizons are best suited for small cap value and small cap growth. This is contrary to our initial hypothesis that the longer the investment horizon, the less relevant is investment style. Our study shows that investment style is relevant to investment horizon such that the expected return is a function of the investment.

This study adds to the literature by supporting and extending the work of Lin (2006) on Taiwan mutual fund using US mutual funds. Lin examined the determinants of mutual fund performance over different investment horizons. Lin finds that the fund performance is relevant with the length of the investment horizon. Lin also finds that growth and income funds have the best performance when the investment horizon is less than three years. However, for horizon between three and four years, growth funds are better while aggressive-growth funds are the best when investment horizon is less than one year and greater than four years. This is in agreement with our finding on the role of small cap value and growth and large cap value and growth funds.

\section{References}

Arugaslan, O., Edwards, E., \& Samant, A. (2007). Evaluating large US-based equity mutual funds using 
risk-adjusted performance measures. International Journal of Commerce and Management, 17(1/2), 6-24. http//dx.doi.org/101108/10609210710774721

Booth, L., \& Chang, B. (2011). Target-date funds: good news and bad news. The journal of Risk, 13(3), 55-82.

Cashman, F. D., Nardari, F., Deli, D. N., \& Villupuram, S. V. (2012). Investor behavior in the mutual fund industry: Evidence from gross flows. $J$ Econ Finan, 38, 430-467. http//dx.doi.org/10.1007/s12197-012-9231-1

Chander, M. (2002). An Evaluation of Portfolio Performance Components Across Fund Characteristics. Finance India, 16(4), 1377-1391.

Haslem, J. A. (2014). Morningstar mutual fund measures and selection model. The Journal of Wealth Management, 17(2), 19-30.

Holmes, K. A., \& Faff, R. W. (2007). Style drift, fund flow and fund performance: new cross-sectional evidence. Financial Services Review, 16(1), 55-71.

Investment Company factbook. (2018). Retrieved from http://www.ici.org/pdf/2018_factbook.pdf Jones, M. A., Lesseig, V. P., \& Smythe, T. I. (2005). Financial Advisors and mutual fund selection. Journal of Financial Planning, 18(3), 64-70.

Lin, M. (2006). An Examination of the Determinants of Mutual Fund Performance Over Different Investment Horizons. International Journal of Management, 23(1), 147-156.

Lobão, J., \& Gomes, S. C. (2016). Performance and Characteristics of Mutual Funds: Evidence from the Portuguese Market. Gestão, Finaças e Contabilidade, 5(4), 125-148. http//dx.doi.org/10.18028/2238-5320/rgfc

Nanigia, D. (2016). Updated advice on mutual fund selection. Journal of Financial Planning, 36-37.

Nihar, K. L., \& Murty, K. S. (2010). Mutual fund performance: A review. A Management Journal, 1(2), 89-102.

Peterson, J. D., Pietranico, P. A., Riepe, M. W., \& Xu, F. (2002). Explaining after-fax mutual fund performance. Financial Analysis Journal, 58(1), 75-86.

Smith, M., \& Gerrans, (2012). Mutual fund selection criteria: Evidence from Malaysia. Asian Review of Accounting, 20(2), 140-151. http//dx.doi.org/10.1108/13217341211242187

Switzer, L. N., \& Huang, Y. (2007). How does human capital affect the performance of small and mid-cap mutual funds? Journal of Intellectual Capital, 8(4), 666-681. http//dx.doi.org/10.1108/14691930710830828

\section{Copyrights}

Copyright for this article is retained by the author(s), with first publication rights granted to the journal.

This is an open-access article distributed under the terms and conditions of the Creative Commons Attribution license (http://creativecommons.org/licenses/by/4.0/). 